\title{
Morphological study of edible and non- edible mushrooms, district Swabi, Khyber Pakhtunkhwa, Pakistan
}

\author{
Tabassum Yaseen ${ }^{1 *}$, Mubashir Khan $^{1}$, Muhammad Shakeel ${ }^{2}$ and Hussan \\ $\mathrm{Ara}^{3}$ \\ 1. Department of Botany, Bacha Khan University, Charsadda, Khyber Pakhtunkhwa-Pakistan \\ 2. Department of Biotechnology, Bacha Khan University Charssada, Khyber Pakhtunkhwa-Pakistan \\ 3. Deportment of Botany, Abdul Wali Khan University Mardan, Khyber Pakhtunkhwa-Pakistan \\ *Corresponding author's email: sciences111@yahoo.com
}

Citation

Tabassum Yaseen, Mubasheer Khan, Muhammad Shakeel and Hussan Ara . Morphological study of edible and nonedible mushrooms, district Swabi, Khyber Pakhtunkhwa, Pakistan. Pure and Applied Biology. Vol. 5, Issue 4, pp889-894. http://dx.doi.org/10.19045/bspab.2016.50112

\begin{tabular}{llll}
\hline \hline Received: 14/06/2016 & Revised: 03/08/2016 & Accepted: 10/08/2016 & Online First: 22/08/2016 \\
\hline
\end{tabular}

\section{Abstract}

District Swabi is located in the province Khyber Pukhtoonkhawa, Pakistan coordinates with Sawabi is lies at ' $34^{\circ} 7^{\prime} 0 \mathrm{~N} 72^{\circ} 28^{\prime} 0 \mathrm{E}^{\prime}$ ' with diversified ecosystem. The mushroom identification of Swabi has not been consider important in the past in this matter. Thus survey was conducted during 2014-15 in different areas of the District Swabi. Twenty two mushroom species belonging to 13 families and 18 genera were collected and investigated from the area. Among the collected mushroom species Polyporaceae was found as most predominant genus $(25 \%)$ followed by Agaricaceae (20\%). There is a great variation in all species because of habitats, seasons and location.

Keywords: Swabi; Mushroom; Agaricaceae; Agaricacea; Habitats

\section{Introduction}

Sawabi is a District of Khyber Pakhtunkhwa province of Pakistan. It lies at " $34^{\circ} 7^{\prime} 0 \mathrm{~N}$ $72^{\circ} 28^{\prime} 0 E^{\prime}$ '. Total area of District Swabi is $1,543 \mathrm{Km}^{2}(595.8 \mathrm{Sq} . \mathrm{mi})$ and in 2005 survey total populations is $1,826,804$. Cash crop of Swabi is tobacco, along with others vegetables and cereals. It's suited for citrus specially, but some other fruits are also grown [1]. Mushrooms are eukaryotic classified in the kingdom Fungi. Recent estimates suggest that there are 5.1 million fungi species worldwide [2]. Mushrooms are macro fungi belong to basidiomycota or ascomycota which may be hypogeous or epigeous, in the form of and above ground and underground seen with the naked eye and picked up by hand [3]. The fruiting bodies are the morphological indices which having spores and said to be mushrooms. Mushrooms are diverse group of fungi. mushroom can be edible or inedible regardless of its form and type. According to the mode of life mushrooms are recognized as saprotrophs, parasites, and mutualists ectomycorrhizal symbionts [4]. "Among the unexplored and unexamined mushrooms, if the proportion of useful mushroom is $5 \%$, it suggests that 7000 undiscovered species would possibly provide benefit to mankind" [5]. Edible mushrooms have been traditionally 
appreciated due to their best characters, like their unique fragrance and flavor [6]. Cultivated and wild edible mushrooms have been showing health enhancement benefits [7]. The most dominant and cultivable mushroom is Agaricus bisporus, followed by Lentinus edodes, Pleurotus spp, and Flammulina velutpes [8-10].

\section{Materials and methods}

\section{Collection site}

Samples of mushrooms were collected from different areas of District Sawbi of province Khyber Pakhtunkhwa, Pakistan. It is lies at $34^{\circ} 7^{\prime} 0$ North $72^{\circ} 28^{\prime} 0$ East and total area of district swabi is $1,543 \mathrm{Km}^{2}$. Relatively average annual rainfall is $639 \mathrm{~mm}$. The annual average temperature of Swabi district is $28.6^{\circ} \mathrm{C}$ and minimum is $10.2^{\circ} \mathrm{C}$ and maximum is $32.9^{\circ} \mathrm{C}$ (Climate. Data.Org).

\section{Collection of mushrooms}

Various species adopted various fruiting bodies phonologies, which are different from season to season and locality to locality. Collections of mushrooms were mad in different seasons (July -August), winter (December.-Jan.), spring (March.April.) and summer (May and June) 201415. Mushrooms were collected carefully by using forceps and hand while the mushrooms growing on their host/habitat were collected along with them. The photographs were made in their natural habitat. Every species was wrapped in the paper envelop along with date of collection, habitat, locality and specimen number.

\section{Identification}

The collected specimens were brought to the laboratory. The phonological characters were recorded for identification and up to species level with the help of available literature, based on the mature mushroom characters [11].

\section{Preservation}

Mushroom species preserve by wet and dry method. For wet preservation mushroom species were kept in bottles and preserved in solution of Formalin.

\section{Results and discussion}

Swabi remains unexplored in terms of existing mushrooms and their potential use. Therefore, a survey was conducted in different areas during different seasons (2014-15). Total of 22 spp. Agaricus arvensis, Coprinus comatus, Lepiota oreadiformis, Chlorophyllum brunneum, Coprinellus disseminates, Coprinellus micaceus, Coprinopsis atramentaria, Fomes fomentarius, Polyporus alveolaris, Trametes gibbosa, Trametes versicolor, Spongipellis pachyodon, Pleurotus ostreatus, Fomitopsis pinicola, Daldinia concentrica, Bolbitius titubans, Ganoderma applanatum, Coprinus sterquilinus, Abortiporus biennis, Panellus mitis, Laccaria amethystine, belong to 13 (families) and 18 (genera) were investigated (Table 1 and Figure.1). All data regarding phonological features were shown(Table1).

Table 1. Morphological studies of Mushrooms collected from District Sawabi

\begin{tabular}{|l|l|l|l|l|l|l|}
\hline S.No & Scientific Name & Family & Location & Habitat & Season & Edibility \\
\hline $\mathbf{1}$ & Agaricus arvensis & Agaricaceae & Swabi & $\begin{array}{l}\text { Fields and grassy } \\
\text { areas }\end{array}$ & March-August & $\begin{array}{l}\text { Use for the } \\
\text { treatment of ulcers }\end{array}$ \\
\hline $\mathbf{2}$ & Coprinus comatus & Agaricaceae & Swabi & Green areas & $\begin{array}{l}\text { October- } \\
\text { November }\end{array}$ & Inedible \\
\hline $\mathbf{3}$ & Lepiota oreadiformis & Agaricaceae & Swabi & On ground, in humus & July-December & Inedible \\
\hline $\mathbf{4}$ & Chlorophyllum brunneum & Agaricaceae & Swabi & Near compost heaps & $\begin{array}{l}\text { September- } \\
\text { December }\end{array}$ & Edible \\
\hline $\mathbf{5}$ & Coprinellus disseminatus & Psathyrellaceae & Swabi & $\begin{array}{l}\text { Wood and shaded } \\
\text { hedgerow }\end{array}$ & $\begin{array}{l}\text { October- } \\
\text { November }\end{array}$ & Edible \\
\hline $\mathbf{6}$ & Coprinellus micaceus & Psathyrellaceae & Swabi & On buried wood & July-December & Inedible \\
\hline
\end{tabular}


Pure Appl. Biol., 5(4): 889-894, December, 2016

http://dx.doi.org/10.19045/bspab.2016.50112

\begin{tabular}{|c|c|c|c|c|c|c|}
\hline 7 & Coprinopsis atramentaria & Psathyrellaceae & Swabi & $\begin{array}{l}\text { buried wood and } \\
\text { grassland }\end{array}$ & $\begin{array}{l}\text { December- } \\
\text { March }\end{array}$ & Edible, poisonous \\
\hline 8 & Fomes fomentarius & Polyporaceae & Swabi & Grows on wood & July-December & Inedible \\
\hline 9 & Polyporus alveolaris & Polyporaceae & Swabi & on dead hard wood & February-May & Inedible, antifungal \\
\hline 10 & Trametes gibbosa & Polyporaceae & Swabi & $\begin{array}{lll}\begin{array}{l}\text { stumps } \\
\text { wood }\end{array} & \text { and } & \text { dead } \\
\end{array}$ & July-December & Inedible \\
\hline 11 & Trametes Versicolor & Polyporaceae & Swabi & Grows in tiled layers & July-December & anti-cancer, \\
\hline 12 & Spongipellis pachyodon & Polyporaceae & Swabi & $\begin{array}{l}\text { Parasitic on oaks and } \\
\text { wood }\end{array}$ & March-February & Inedible \\
\hline 13 & Pleurotus ostreatus & Pleurotaceae & Swabi & Decomposer of wood & July-December & Edible \\
\hline 14 & Fomitopsis pinicola & Fomitopsidaceae & Swabi & $\begin{array}{l}\text { On live conifer, } \\
\text { eucalyptus }\end{array}$ & February-April & Inedible \\
\hline 15 & Cantharellus cibarius & Cantharellaceae & Swabi & $\begin{array}{ll}\begin{array}{l}\text { On } \\
\text { herbs }\end{array} & \text { low-growing } \\
\end{array}$ & June-July & $\begin{array}{l}\text { Antioxidant } \\
\text { Anti-microbial }\end{array}$ \\
\hline 16 & Daldinia concentrica & Xylariaceae & Swabi & $\begin{array}{l}\text { Lives on dead and } \\
\text { decaying wood }\end{array}$ & July-December & For fire lighting \\
\hline 17 & Bolbitius titubans & Bolbitiaceae & Swabi & $\begin{array}{l}\text { Dung or heavily } \\
\text { fertilized soil }\end{array}$ & $\begin{array}{l}\text { October- } \\
\text { November }\end{array}$ & Poisonous \\
\hline 18 & Ganoderma applanatum & $\begin{array}{l}\text { Ganodermatacea } \\
\mathrm{e}\end{array}$ & Swabi & $\begin{array}{lll}\begin{array}{l}\text { Decaying } \\
\text { stumps }\end{array} & \operatorname{logs} \text { and } \\
\end{array}$ & July-December & Inedible \\
\hline 19 & Coprinus sterquilinus & Coprinaceae & Swab & $\begin{array}{l}\text { Horse manure and } \\
\text { straw }\end{array}$ & $\begin{array}{l}\text { September- } \\
\text { November }\end{array}$ & Edible \\
\hline 20 & Abortiporus biennis & Meruliaceae & Swabi & Dead and living trees & $\begin{array}{l}\text { September- } \\
\text { December }\end{array}$ & Inedible \\
\hline 21 & Panellus mitis & Mycenaceae & Swabi & On woods & $\begin{array}{l}\text { Septembert- } \\
\text { December }\end{array}$ & Inedible \\
\hline 22 & Laccaria amethystine & Hydnangiaceae & Swabi & $\begin{array}{l}\text { In woods, } \\
\text { On ground }\end{array}$ & $\begin{array}{l}\text { September- } \\
\text { December }\end{array}$ & Edible \\
\hline
\end{tabular}

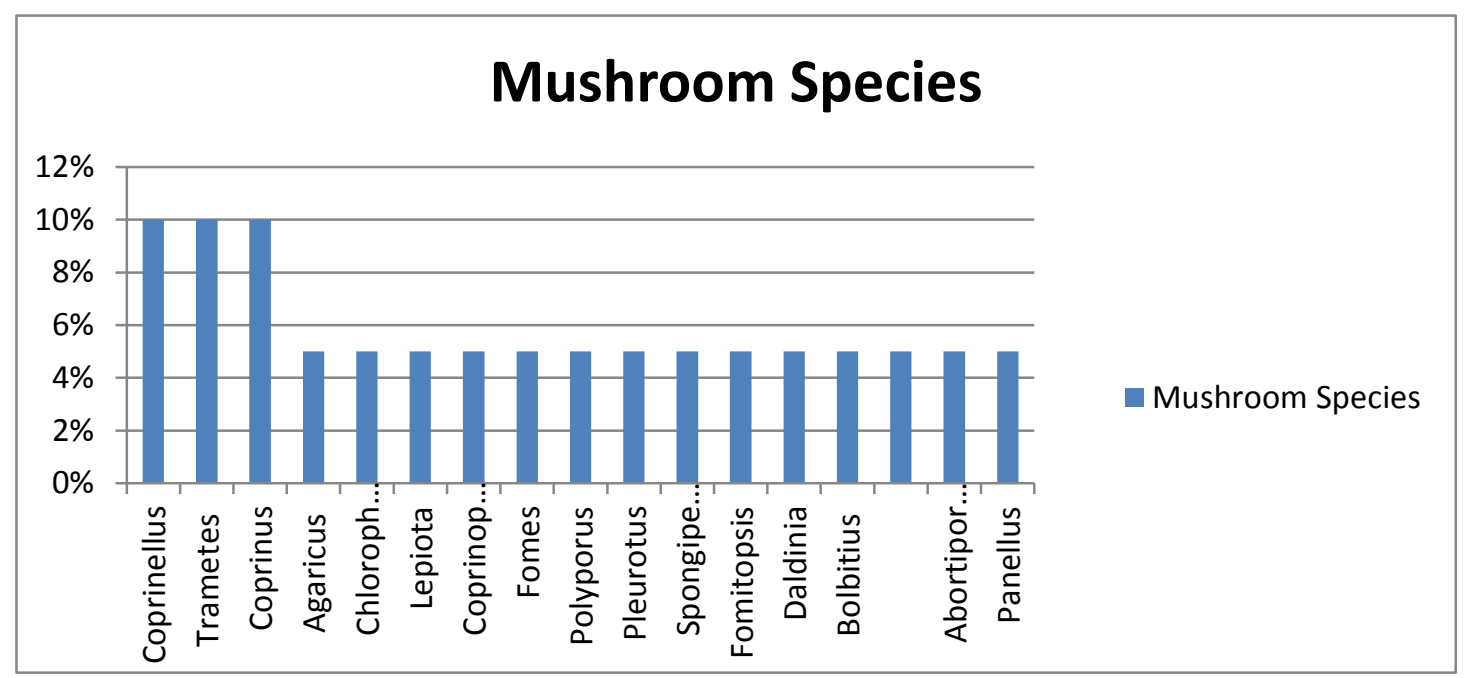

Figure 1. Mushroom are show Percentage composition 
Data showed that Polyporaceae was dominant family $(25 \%)$ represented by 5 spp. followed by Agaricaceae (20\%) as another major family with 4 species and Psathyrellaceae is the third major family of the study area (Table1 and Figure. 2) there is great variations among mushrooms species these differences were seen in their ediabl $(30 \%)$, non ediable $(50 \%)$ and poison (20\%) form which show their economics importance (Figure 3) our results match with the statement

[12].

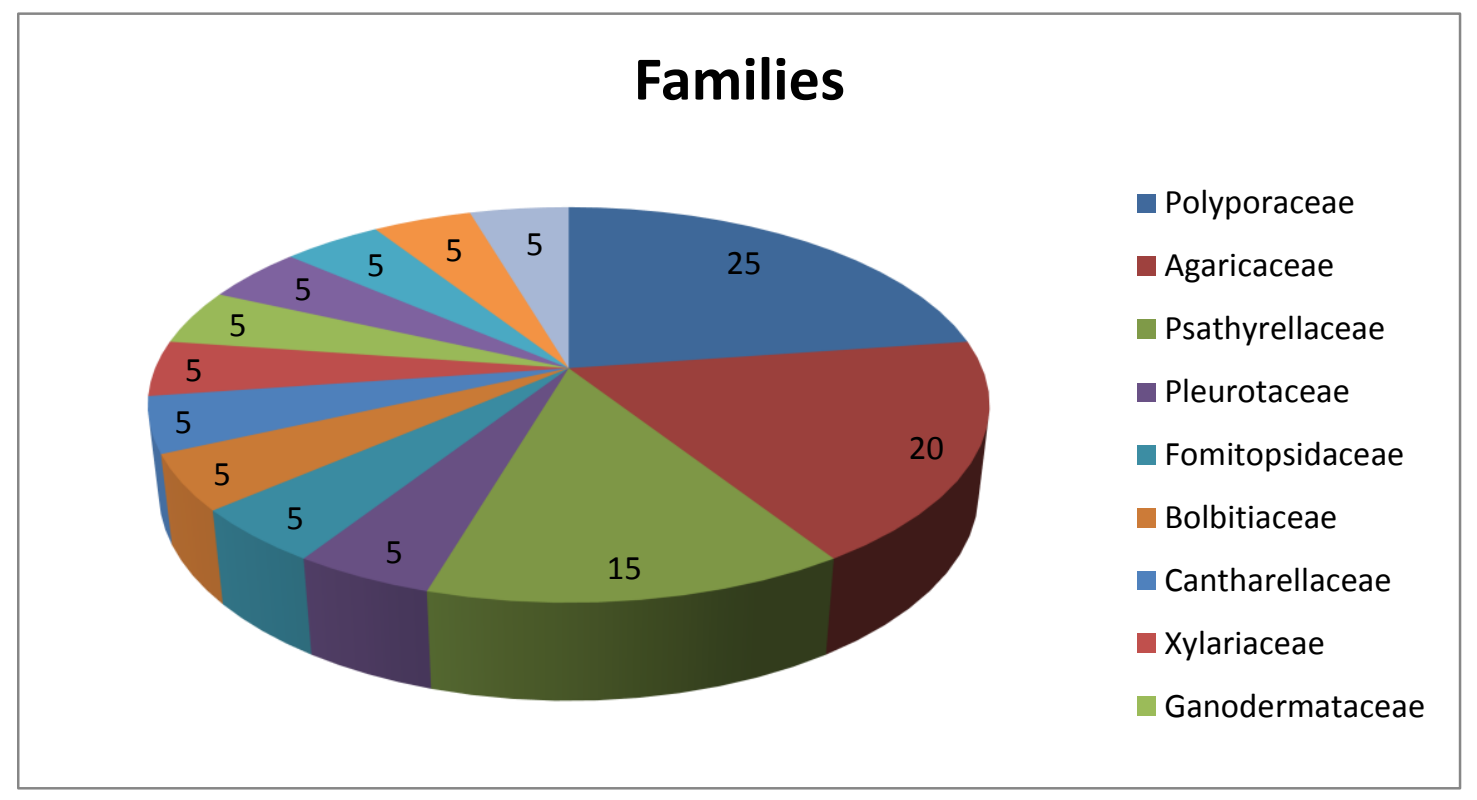

Figure 2. Occurrence of mushroom spp. in various Families

Mushrooms lifestyle unique lives as symbiotic, saprophytic and parasitic. These variation because of variation in soil structure, soil texture, soil moisturizing, saprobes and as temperature. In present work, wood was pronounced habitat, $14 \mathrm{spp}$. were present on living and dead woods, while $7 \mathrm{spp}$. were investigated on soil and 1 spp. on dung (Figure 4). These variations in various habitat were because of their specific nutritional mode. Results correlate with [13-15]. Mushrooms used and consumed throughout the year, but mostly mushrooms are collected in the rainy seasons, which show their value of rain fall patterns in phenology also match with the findings of authors [16]. Who worked on the diversity of macro fungi that Some species were present in both rainy seasons and early dry seasons. 


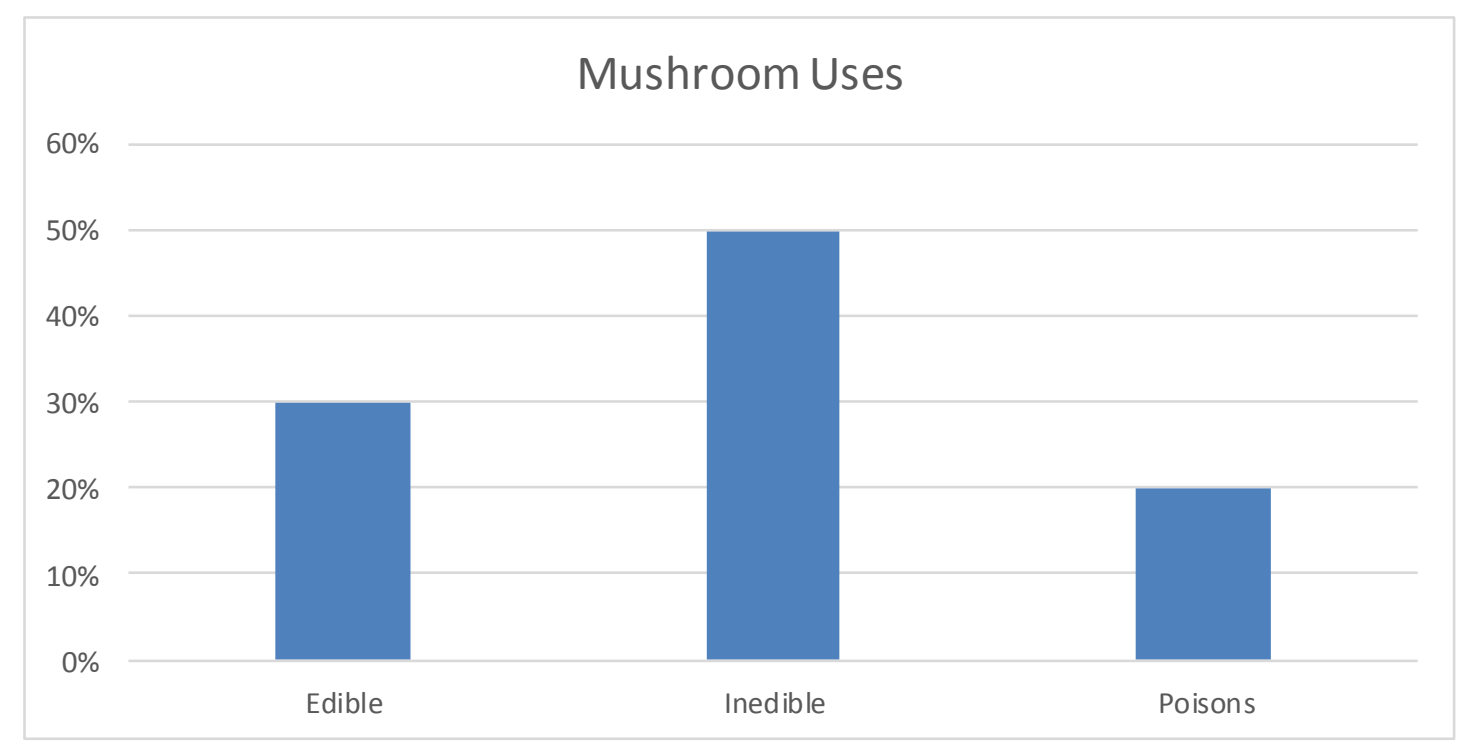

Figure 3. Economic importance of different mushroom species

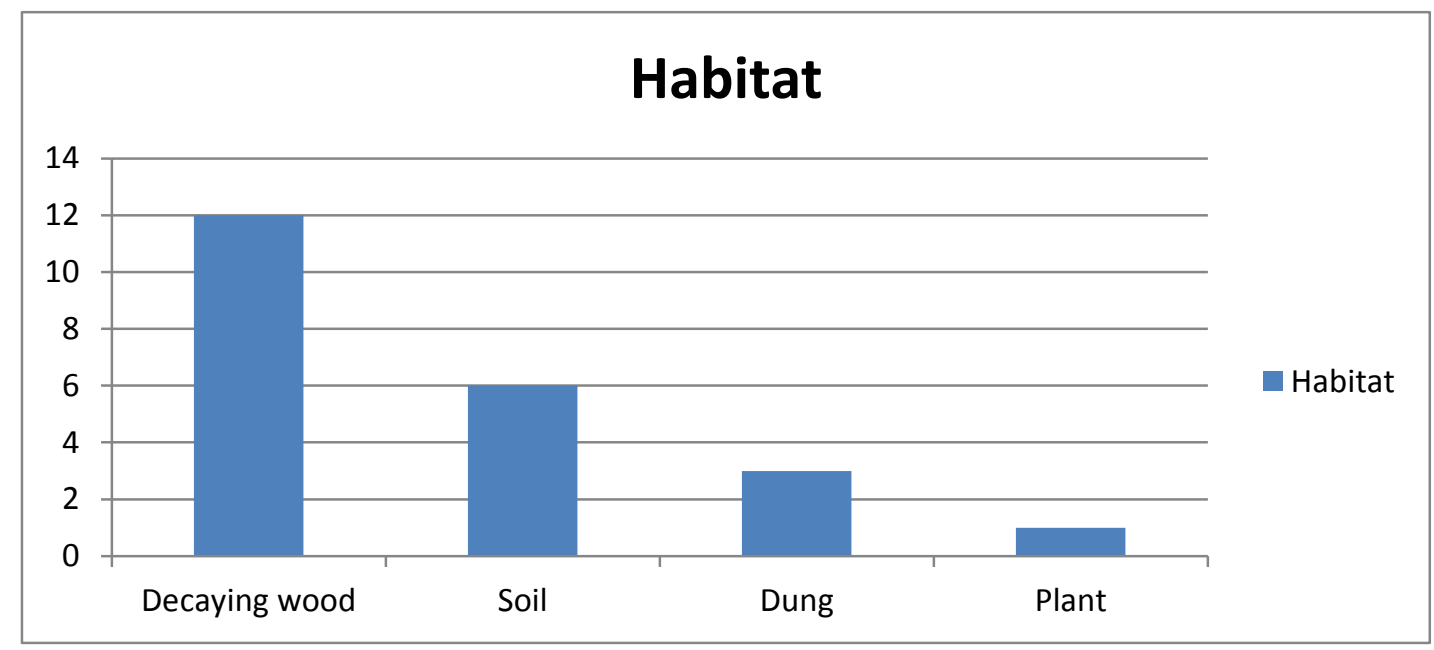

Figure 4. Mushroom Percentage affected by different habitat

\section{Conclusion and recommendations}

Population of study area is not highly dependent on wild mushrooms as they used only those mushrooms as food which is available during rainy season. They have no knowledge regarding to their medicinal value. Mushroom flora is going to extinct due to deforestation, urbanization and less interest of peoples. Moreover, regular studies should be conducted to keep the record of mushroom flora of the area. This was fist report on record of mushrooms of Swabi. This research would serve as baseline information for the future researchers in the study area.

\section{Authors' contributions}

Conceived and designed the experiments: $\mathrm{T}$ Yaseen \& $M$ Khan, Performed the experiments: M Khan, Analyzed the data: T Yaseen \& M Khan, Contributed reagents/ materials/ analysis tools: M Shahkeel \& $\mathrm{H}$ Ara, Wrote the paper: T Yaseen \& M Khan. 


\section{References}

1. Heer (2005). Divisions \& Subdivisions of Pakistan.

2. Blackwell M (2011). The fungi: 1, 2, $3 \ldots$ 5.1 million species? Am J Bot 98: 426438.

3. Kues U \& Liu Y (2000). Fruiting body production in basidiomycete. Appl. Microbiol. Biotechnol, 54: 141-152.

4. Gadd GM (2008). Fungi and their role in the biosphere. In Jorgensen SE, Fath, B (eds) Encyclopedia of ecology. Elsevier Amsterdam 1709-1717.

5. Hawksworth DL (2001). The magnitude of fungal diversity: the 1.5 million species estimate revisited. Mycological Research 105: 1422-1432.

6. Chiron N, Michelot D \& champignons OD (2005). Chimie et rôle dans les interactions biotiques-Une revue. Cryptogam. Mycol 26: 299-364.

7. Chang ST \& Miles PG (2008). Mushrooms, Cultivation, Nutri-tional Value, Medicinal Efect, and Environmental Impact. CRC Press Boca Raton Fla, USA. 2nd Edition.

8. Chang ST \& Wasser SP (2012). The role of culinary-medicinal mushrooms on human welfare with a pyramid model for human health. Int J Med Mushrooms 14: 95-134.

9. Aida FMNA, Shuhaimi M, Yazid M \& Maaruf AG (2009). Mushroomas a potential source of prebiotics: a review. Trendsin Food Science \& Technology, 20(11-12): 567-575.
10. Patel S \& Goyal A (2012). Recent developments in mushrooms as anticancer therapeutics: a review. Biotech 2(1): 1-15.

11. Kishwar S, Gul M, Firdous SS \& Asghar R (2007). Hymenomycetes from Multan District. Pak J Bot 39(2): 651-657.

12. Okhuoya JA, Akpajae O, Osemwegie O $\mathrm{O}$, Oghenekaro AO \& Ihayere CA (2010). Nigerian Mushrooms: Underutilized Non-Wood Forest Resources. J Appl Sci Environ Manag 14(1): 43-54

13. Adekunle VAJ \& Ajao K (2005). Contributions of edible mushrooms (A non-timber forest product of tropical ecosystem) to rural livelihood in Oyo State, Nigeria. Pak J Soc Sci 3(5):809812.

14. Dijki HV, Onguene NA \& Kuyper T W (2003). Knowledge and utilization of edible mushrooms by local populations of the rain forest of South Cameroon. Ambio 32: 19-23.

15. Gbolagade JS, Ajayi A, Oku I \& Wankasi D (2006). Nutritive value of common wild edible mushrooms from southern Nigeria. Global Journal of Biotechnology and Biochemistry 1(1):16 21.

16. Swapna S, Syed A \& Krishnappa M (2008). Diversity of macro fungi in semi-evergreen and moist deciduous forest of Shimoga District Karnataka, India. . Mycol Plant Pathol 38(1):21 26. 